\title{
Stability of a Catabolic Plasmid in Continuous Culture
}

\author{
By T. KESHAVARZ, M. D. LILLY AND PATRICIA H. CLARKE* \\ Department of Chemical and Biochemical Engineering, University College London, \\ Torrington Place, London WCIE $7 J E, U K$
}

(Received 25 September 1984; revised 18 December 1984)

\begin{abstract}
A wild-type strain of Pseudomonas putida PPK1, carrying a non-conjugative TOL plasmid, was grown in continuous culture under carbon-limitation with $m$-toluate as growth substrate. When the medium was changed to benzoate a plasmid-free strain appeared after about $100 \mathrm{~h}$. After this event the proportion of plasmid-containing bacteria declined rapidly but in several experiments this was followed by oscillations in the relative frequencies of the plasmid-free and plasmid-containing populations. About $1 \%$ of the total population retained the plasmid after $600 \mathrm{~h}$ growth under benzoate-limitation. When the input medium was returned to $m$-toluate the plasmid-free bacteria disappeared and the $\mathrm{TOL}^{+}$population recovered to $100 \%$. The plasmid in the wild-type strain was stably maintained during $500 \mathrm{~h}$ of chemostat growth under succinatelimitation. $\mathrm{Tol}^{+}$strains re-isolated from continuous culture under benzoate-limitation retained their TOL plasmids for longer periods. It is suggested that plasmid loss is related to a failure in the control of partitioning at cell division but that this is not absolute and allows the maintenance of a residual low level of plasmid-containing bacteria in the population.
\end{abstract}

\section{INTRODUCTION}

Many bacteria contain plasmids coding for such characters as drug resistance or the ability to utilize certain organic compounds which are of advantage to the host only under particular growth conditions. Nevertheless, it is clearly advantageous to a natural population of bacteria to retain such plasmids in order to survive in a changing environment. In some cases a plasmid may provide both catabolic genes and drug resistance genes (Kanemitsu et al., 1980) or a plasmid may render its host more resistant to UV irradiation or some other toxic hazard (Jacoby, 1974). The disadvantage of possessing plasmids has been considered to be that they place a significant burden on the bacterial host (Dykhuizen \& Hartl, 1983). The implication of this view was that under non-selective growth conditions the plasmid-free bacteria would have a growth advantage and outgrow the original population. It was also predicted that the size of the plasmid would be directly related to its effect on the growth rate of the bacterial host. Recent work has shown that this simple relationship does not always hold (Dykhuizen \& Hartl, 1983; Nordstrom, 1983; Zund \& Lebek, 1980). The stability of drug resistance plasmids in continuous culture has been examined by Melling et al. (1977) and Godwin \& Slater (1979). We have studied the stability of a catabolic plasmid in continuous culture. TOL plasmids are widely distributed in nature and strains carrying these plasmids can be isolated by selective enrichment on $m$-toluate (Williams \& Worsey, 1976). The original TOL plasmid was identified in Pseudomonas putida (arvilla) strain $\mathrm{mt}-2$ by Williams \& Murray (1974). The TOL plasmid of strain $\mathrm{mt}-2$ (PaW1) carries genes for the catabolism of toluene, $m$ - and $p$-xylene, and their intermediates, via the meta cleavage pathway. Benzoate is catabolized via the meta pathway in strains carrying TOL plasmids but cured strains break down benzoate by the ortho cleavage pathway coded by chromosomal genes. Strain $\mathrm{PaW}$, and some strains carrying other TOL plasmids, can be cured by growth on benzoate (Williams \& Murray, 1974; Williams \& Worsey, 1976). Extensive rearrangements of the TOL plasmid DNA may take place under selection for growth on benzoate and the chlorobenzoates (Jeenes et al., 1982). 
In this study we have examined the stability of a TOL plasmid of a natural isolate of $P$. putida in chemostat culture with $m$-toluate, benzoate or succinate as the growth-limiting substrates. The strain used was a recent isolate so as to avoid as far as possible the changes that might result from prolonged laboratory cultivation. The plasmid was non-conjugative in batch culture so it was unlikely that the results would be complicated by plasmid transfer from $\mathrm{TOL}^{+}$to $\mathrm{TOL}^{-}$ bacteria during chemostat growth.

\section{METHODS}

Bacterial strains. The strains are listed in Table 1. P. putida strain PPK 1 was isolated from enrichment culture on $m$-toluate of a soil sample from the London area. Cured strains were isolated from batch or continuous culture and auxotrophic and drug-resistant mutants were isolated by standard methods. The sources of other strains are given in Table 1.

Growth media. Nutrient broth and agar were prepared with Oxoid Nutrient Broth no. 2. The minimal salts medium was based on that described by Brammar \& Clarke (1964) and the specified carbon source was added to give the required concentration for each experiment. Dilution buffers and media for batch experiments were sterilized by autoclaving at $121^{\circ} \mathrm{C}$ for $15 \mathrm{~min}$. The 20 litre vessels used for media reservoirs for continuous culture experiments were autoclaved for $40 \mathrm{~min}$.

Batch growth. Small volumes of culture (about $5 \mathrm{ml}$ ) were grown in universal screw-capped bottles. Larger volumes were grown in conical flasks $(250-1000 \mathrm{ml})$. Cultures were incubated at $30^{\circ} \mathrm{C}$ (or $37^{\circ} \mathrm{C}$ ) on a mechanical shaker, either reciprocating or orbital in operation. In some experiments a chemostat vessel was used for batch culture with appropriate rates of forced aeration.

Continuous culture. Two types of vessels were used. Some experiments were carried out with a New Brunswick BioFlo model C30 with a culture volume of $300 \mathrm{ml}$ stirred at 400 r.p.m. and sparged with water-saturated air to prevent loss of water vapour during aeration. Other experiments were carried out with a glass bioflow fermenter with a working volume of $150 \mathrm{ml}$ designed at University College London. Sampling points were located in the overflow lines of each fermenter for the removal of large samples $(30 \mathrm{ml})$ which were directed into sterile bottles cooled on ice. Small samples of about $1 \mathrm{ml}$ were taken directly from the fermenter vessels by means of sterile syringes.

For each experiment the culture vessel was inoculated with $10 \%(v / v)$ of an overnight culture and when the culture was approaching the end of the exponential phase of growth, continuous flow operation was started. The dilution rate was kept constant at $0 \cdot 2 \mathrm{~h}^{-1}$. The concentrations of carbon sources were $m$-toluate $5 \mathrm{~mm}$, benzoate $5.5 \mathrm{~mm}$ and succinate $10 \mathrm{~mm}$, as the sodium salts. Polypropylene glycol antifoam was added to the medium $\left(0 \cdot 1 \mathrm{ml} \mathrm{l}^{-1}\right)$. When steady state conditions had been established for growth on $m$-toluate the medium was changed to benzoate or succinate.

Bacterial counts and growth phenotypes. The bacterial concentration of batch and chemostat cultures was obtained by measuring the optical density at $675 \mathrm{~nm}$ with a Pye Unicam SP600 spectrophotometer. Total counts were obtained by plating suitable dilutions of cultures on nutrient agar plates and samples of the same, or other, dilutions were spread on minimal agar plates containing $m$-toluate, succinate or benzoate as the sole carbon source. Plates were incubated at $30^{\circ} \mathrm{C}$ until colonies were large enough to be counted. The apparent loss of the TOL plasmid was calculated from the number of colonies on $m$-toluate plates compared with the numbers on nutrient,

Table 1. Bacterial strains and plasmids

\begin{tabular}{|c|c|c|c|c|}
\hline Strain & $\begin{array}{c}\text { Relevant } \\
\text { phenotype† }\end{array}$ & Plasmid & Origin & Reference \\
\hline \multicolumn{5}{|l|}{ P. putida } \\
\hline PPK 1 & $\mathrm{Tol}^{+}$ & pTK0 & Isolate from $m$-toluate & This paper \\
\hline PPK 1* & $\mathrm{Tol}^{+}$ & pTK0 & see text and Fig. $1(a)$ & This paper \\
\hline PPK2 & $\mathrm{Tol}^{-}$ & None & see text and Fig. $1(b)$ & This paper \\
\hline PPK 2 str-204 & $\mathrm{Tol}^{-} \mathrm{Str}^{\mathrm{r}}$ & None & PPK2 & This paper \\
\hline PPK6 & $\mathrm{Tol}^{+}$ & PTK0 & see text and Fig. 3 & This paper \\
\hline PPK I(pMO61) & $\mathrm{Tol}^{+} \mathrm{Cb}^{r} \mathrm{Km}^{r}$ & pTK0, pMO61 & Conjugal transfer & This paper \\
\hline PaWl & Tol $^{+}$ & pWW0 & Wild-type & Williams \& Murray (1974) \\
\hline PaW17 & $\mathrm{Tol}^{-} \mathrm{Str}^{\mathrm{r}}$ & None & Benzoate curing & Williams \& Murray (1974) \\
\hline $\begin{array}{l}\text { P. aeruginosa } \\
\text { PAC21 } \\
\text { PAO127 }\end{array}$ & $\begin{array}{l}\text { Tol }^{-} \text {Lys }^{-} \\
\text {Tol- }^{-}\end{array}$ & $\begin{array}{l}\text { None } \\
\text { pMO61 }\end{array}$ & $\begin{array}{l}\text { PACl } \\
\text { PAO1 }\end{array}$ & $\begin{array}{l}\text { Laboratory collection } \\
\text { Morgan (1982) }\end{array}$ \\
\hline
\end{tabular}

† Phenotype designations: $\mathrm{Tol}^{+}$, ability to grow on $m$-toluate; Lys ${ }^{-}$, lysine auxotrophy; $\mathrm{Str}^{\mathrm{r}}$, resistance to streptomycin $\left(200 \mu \mathrm{g} \mathrm{ml}^{-1}\right) ; \mathrm{Cb}^{r}, \mathrm{Km}^{r}$, resistance to carbenicillin $\left(500 \mu \mathrm{g} \mathrm{ml}^{-1}\right)$ and kanamycin $\left(250 \mu \mathrm{g} \mathrm{ml}^{-1}\right)$ coded on plasmid pMO61. 
benzoate or succinate agar plates and was expressed as percentage loss. The colonies from nutrient agar plates (or succinate agar plates) were also replicated onto $m$-toluate plates. Cured $\mathrm{Tol}^{-}$strains were selected in this manner. Isolates were tested for growth on $m$-xylene and toluene.

Isolation of streptomycin-resistant mutants. The strains used in mating experiments were selected on nutrient agar plates containing streptomycin and were resistant to $200 \mu \mathrm{g}$ streptomycin $\mathrm{ml}^{-1}$.

Conjugation experiments. Tests for conjugal transfer were carried out by plate mating or by membrane mating (Austen \& Dunn, 1977).

Plasmid mobilization. Plasmid pMO61 derived by Morgan (1982) from the IncP-1 plasmid R68.45 was used for mobilizing the TOL plasmid pTK0 using the method of Austen \& Dunn (1977). Plasmid pMO61 was transferred into PPK strains from $P$. aeruginosa strain PAC21 lys(pMO61) by plate mating on $m$-toluate minimal agar plates supplemented with $400 \mu \mathrm{g}$ kanamycin $\mathrm{ml}^{-1}$.

Cell-free extracts. Samples from the continuous cultures were centrifuged and the bacteria were stored at $-20{ }^{\circ} \mathrm{C}$ until required. The bacterial pellet was resuspended in $0 \cdot 1 \mathrm{M}$-phosphate buffer $\mathrm{pH} 7 \cdot 6$, supplemented with $10 \%(\mathrm{v} / \mathrm{v})$ acetone, and disrupted by sonication. The bacterial debris was removed by centrifugation at $15000 \mathrm{~g}$ for $15 \mathrm{~min}$ and the supernatant kept on ice until enzyme assays were completed.

Enzyme assays. Spectrophotometric assays were carried out at room temperature using a Pye Unicam SP 1700 spectrophotometer. Reactions were started by the addition of $0.1 \mathrm{ml}$ of the crude extract to the cuvette containing the reaction mixture. Units were defined as the amount of enzyme converting 1 nmol of substrate to the product in 1 min under the assay conditions used. Catechol 1,2-oxygenase (pyrocatechase) was measured by the increase in absorbance due to the production of cis,cis-muconate (Hegeman, 1966). Catechol 2,3-oxygenase was measured by the methods described by Sala-Trepat \& Evans (1971) following the increase in absorbance due to the production of 2-hydroxymuconic semialdehyde.

Plasmid isolation. Samples for plasmid isolation containing glycerol $(16 \%, \mathrm{v} / \mathrm{v})$ were preserved at $-70{ }^{\circ} \mathrm{C}$. The methods of Wheatcroft \& Williams (1981) were used to isolate plasmid DNA.

Characterization of $m$-toluate isolate PPK1. Electron microscopy showed that the PPK 1 bacteria were short rods with single polar flagella; the Gram strain was negative; PPK 1 grew at $4{ }^{\circ} \mathrm{C}$ and not at $37^{\circ} \mathrm{C}$ or $41^{\circ} \mathrm{C}$; optimal growth was at $30^{\circ} \mathrm{C}$. In growth habit it behaved as an aerobe and colonies on succinate (and other) minimal salts media were faintly yellow with slight fluorescence. Other comparisons were limited to the nutritional criteria of Stanier et al. (1966) and indicated that PPK1 resembled most closely P. putida biotype A. Compounds utilized were: D-glucose, D-fructose, acetate, citrate, DL-lactate, DL-malate, malonate, propionate, pyruvate, succinate, glycerol, ethanol, $n$-propanol, $n$-butanol, iso-butanol, L-alanine, L-aspartate, L-histidine and L-phenylalanine. Compounds not utilized were D-galactose, inositol, methanol, L-tryptophan, anthranilate and acetamide. Strain PPK 1 grew on benzoate, toluene and $m$-xylene as well as on $m$-toluate.

\section{RESULTS}

\section{Plasmid stability in continuous culture with benzoate as carbon-limiting growth substrate}

The experiments were all set up in the same way and growth conditions were kept as constant as possible. Strain PPK 1 and its variants were grown in batch culture until a value of $0.5-0.6$ for $\mathrm{OD}_{675}$ had been reached before switching to continuous operation at a dilution rate of $0.2 \mathrm{~h}^{-1}$. Each experiment comprised four separate growth stages: (A) growth on $m$-toluate and establishment of steady state conditions $(40-100 \mathrm{~h})$; (B) transition from $m$-toluate to benzoate; (C) growth on benzoate and establishment of steady state conditions; (D) transition from benzoate to $m$-toluate and re-establishment of steady state conditions. Experiments were maintained for up to $800 \mathrm{~h}$ and samples taken for determinations of bacterial concentration, plasmid frequency and catechol oxygenase activity. In Table 2 the growth times are given for stages $A+B, C$ and $D$ for the experiments shown in Figs 1-4. At the dilution rate used in these experiments the time for complete medium replacement during stage B was $5 \mathrm{~h}$.

Fig. $1(a, b)$ shows the results obtained for two experiments with PPK 1 for growth during stage C. Zero time is $5 \mathrm{~h}$ after the switch from $m$-toluate to benzoate. In the experiment shown in Fig. $1(a)$ there was a perturbation in optical density after about $80 \mathrm{~h}$ growth and this was paralleled by an apparent loss of plasmid reaching $92 \%$ after $118 \mathrm{~h}$. The optical density began to change at about $160 \mathrm{~h}$ and the culture eventually returned to a steady state of growth and reached a maximum of $98 \%$ plasmid loss. In the experiment shown in Fig. $1(b)$ there was only a slight perturbation in optical density at about the time that plasmid loss was first detected. In other experiments with PPK 1 the extent of the perturbations in optical density observed at about the time at which the plasmid level began to drop was intermediate between the two shown in Fig. 1 . 
Table 2. Plasmid stability in continuous culture with benzoate as carbon-limiting growth substrate

The continuous culture vessel was operated at a dilution rate of $0.2 \mathrm{~h}^{-1}$ with $5 \mathrm{~mm}-m$-toluate as carbon source for at least $40 \mathrm{~h}$ (stage A) before the medium was switched to $5.5 \mathrm{~mm}$-benzoate (stage B, transition to benzoate). At the end of benzoate-growth (stage C) the medium was switched back to $\mathrm{m}^{-}$ toluate (stage D). See text for details.

\begin{tabular}{|c|c|c|c|c|c|c|c|c|c|c|c|}
\hline \multirow[b]{3}{*}{ Strain } & & & & & \multicolumn{5}{|c|}{ Stage C } & \multirow{2}{*}{\multicolumn{2}{|c|}{$\begin{array}{l}\text { Stage D } \\
\text { Plasmid } \\
\text { recovery }\end{array}$}} \\
\hline & \multicolumn{4}{|c|}{ Growth period (h) } & \multicolumn{2}{|c|}{$\begin{array}{l}\text { Plasmid loss } \\
\text { first detected }\end{array}$} & \multicolumn{2}{|c|}{$\begin{array}{l}\text { Maximum } \\
\text { plasmid loss }\end{array}$} & \multirow{2}{*}{ 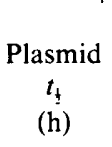 } & & \\
\hline & $A+B$ & $\mathrm{C}$ & D & Total & (h) & $(\%)$ & (h) & $(\%)$ & & (h) & $(\%)$ \\
\hline PPK 1 & 46 & 644 & 164 & 854 & 90 & 6 & 410 & 98 & 96 & 22 & 100 \\
\hline PPK I & 50 & 333 & 26 & 409 & 47 & 3 & 142 & 98 & 92 & 26 & 100 \\
\hline PPK $1^{*} \dagger$ & 49 & 310 & 26 & 385 & 85 & 32 & 150 & 99 & 90 & 30 & 100 \\
\hline PPK $6+$ & 93 & 527 & 51 & 671 & 115 & 16 & 312 & 99 & 130 & 22 & 100 \\
\hline
\end{tabular}

†PPK 1*: inoculum derived from the experiment shown in Fig. $1(a)$. ‡PPK6: inoculum derived from the experiment shown in Fig. 3.

Values for plasmid loss were based on the numbers of $\mathrm{Tol}^{+}$and $\mathrm{Tol}^{-}$bacteria and in later experiments we found that plasmid DNA could be isolated from $\mathrm{Tol}^{+}$bacteria but not from $\mathrm{Tol}^{-}$ bacteria (see Fig. 4). Table 2 gives the times at which plasmid loss was first detected in these and other experiments and the times at which plasmid loss was maximal. Each experiment on population changes in continuous culture is unique (Dykhuizen \& Hartl, 1983) and we shall return to this point later. It was however essential to have some way of comparing one experiment with another and we have used the term plasmid $t_{t}$ for this comparison. This is the time from zero, during growth on benzoate, at which $50 \%$ of the chemostat population had become $\mathrm{Tol}^{-}$. The values for the experiments discussed in this paper are given in Table 2. For the PPK 1 experiment shown in Fig. $1(a)$ the $t_{\frac{1}{2}}$ value was calculated from the time at which the plasmid loss had reached $92 \%$ at the first perturbation rather than the $98 \%$ reached later. In a series of experiments with PPK 1 the values were 90-96 h. Values for the PPK $1^{*}$ and the PPK6 experiments (Figs 3 and $4 a$ ) were also calculated from the first period of rapid plasmid loss.

At the end of stage $\mathrm{C}$ growth on benzoate the chemostats were returned to $m$-toluate as the carbon source. In all cases the optical density fell rapidly but then recovered and the $\mathrm{Tol}^{+}$ population reached $100 \%$ in 20-30 h. Fig. 2 shows the optical density, apparent plasmid levels and enzyme activities during growth stage $\mathrm{D}$, for a typical experiment. The kinetics of growth were consistent with the establishment of a $\mathrm{Tol}^{+}$population frcm the residual plasmidcontaining bacteria. We have taken stage D of the experiment shown in Fig. $1(a)$ as an example but similar recovery rates occurred in all the experiments (see also Fig. $4 a$ ).

One of the objectives of these experiments was to select strains with increased plasmid stability. It was thought that the $\mathrm{Tol}^{+}$survivors during growth on benzoate might be more stable than the original strain. Fig. 3 shows an experiment inoculated with PPK ${ }^{*}$ isolated from a sample taken from the continuous culture shown in Fig. 1(a) after $300 \mathrm{~h}$ growth on benzoate. After about $150 \mathrm{~h}$ the apparent plasmid loss was $99 \%$. After $250 \mathrm{~h}$ there was a marked recovery and the plasmid-free population then dropped to $70 \%$ by $320 \mathrm{~h}$. This experiment demonstrated the spontaneous recovery of plasmid-containing bacteria even under cultural conditions that were expected to provide a strong selection pressure for plasmid loss.

The key meta pathway enzyme coded by the TOL plasmid is catechol 2,3-oxygenase and in each of these experiments the plasmid loss calculated from the ratio of $\mathrm{Tol}^{-} \mathrm{to}^{-} \mathrm{Tol}^{+}$colonies was associated with a decrease in the specific activity of this enzyme. At about the time at which the specific activity of catechol 2,3-oxygenase decreased there was a slight increase in the activity of the ortho pathway enzyme, catechol 1,2-oxygenase (Figs 1-3). (Catechol 1,2-oxygenase is induced by its product, cis,cis-muconate, and would not be expected to reach high levels of activity in cultures grown under carbon-limitation.) The meta pathway enzymes were not investigated in detail, but $\mathrm{Tol}^{+}$and $\mathrm{Tol}^{-}$colonies were tested for growth on other aromatic 


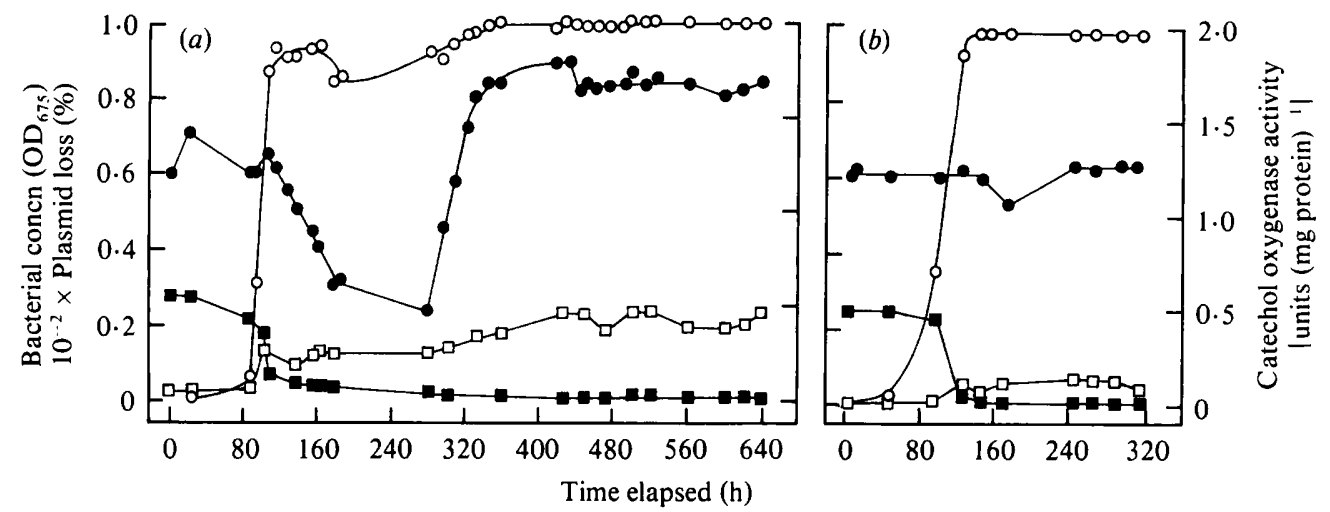

Fig. 1. Growth of $P$. putida strain PPK 1 in continuous culture with benzoate as growth-limiting carbon source. Cultures were grown to steady state with $m$-toluate $(5 \mathrm{~mm})$ and the incoming medium was switched to benzoate $(5.5 \mathrm{~mm})$. The elapsed time is shown for growth on benzoate (stage C). Bacterial concentration as $\mathrm{OD}_{675} ; \mathrm{O}$, percentage plasmid loss; $\square$, catechol 1,2-oxygenase; $\square$, catechol 2,3-oxygenase. The experiments shown in $(a)$ and $(b)$ were carried out under identical conditions of growth.

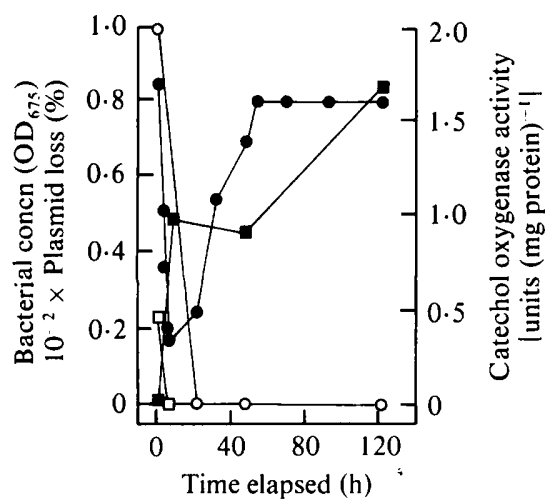

Fig. 2

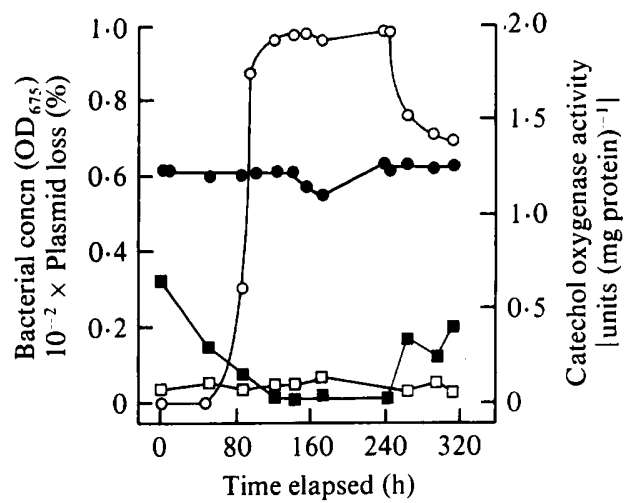

Fig. 3

Fig. 2. Growth of $P$. putida strain PPK 1 in continuous culture following transition from benzoate $(5.5 \mathrm{mM})$ to $m$-toluate $(5 \mathrm{mM})$. Elapsed time is shown for growth on $m$-toluate during stage $\mathrm{D}$, continued from the experiment shown in Fig. $1(a)$ (the designation of the symbols is the same).

Fig. 3. Growth of $P$. putida strain PPK $1^{*}$ in continuous culture with benzoate as growth-limiting carbon source. Cultures were grown to steady state with $m$-toluate $(5 \mathrm{mM})$ and the incoming medium was switched to benzoate $(5.5 \mathrm{~mm})$. The elapsed time is shown for growth on benzoate (stage $\mathrm{C})$. Bacterial concentration as $\mathrm{OD}_{675} ; O$, percentage plasmid loss; $\square$, catechol 1,2-oxygenase; $\square$, catechol 2,3-oxygenase.

compounds. All the $m$-toluate-negative strains obtained were also unable to grow on toluene and $m$-xylene. The appearance of the cultures growing on $m$-toluate was yellowish green and this changed to deep green when the medium was switched to benzoate. At the time of rapid plasmid loss, at about $90 \mathrm{~h}$ in most cases, the colour changed gradually from deep to very pale green.

\section{Variants with altered plasmid stabilities}

Chemostat culture has been widely used to select mutant strains producing altered enzymes or gene duplications (Rigby et al., 1974; Inderlied \& Mortlock, 1977). It was thought that it might be possible to select strains which retained their TOL plasmids for longer periods. There were slight oscillations in plasmid levels in the PPK1 experiment shown in Fig. $1(a)$. Strain PPK1* was isolated from a sample taken after about $300 \mathrm{~h}$ growth on benzoate during stage $\mathrm{C}$ of this experiment and was used as the inoculum for the experiment shown in Fig. 3. Although plasmid 


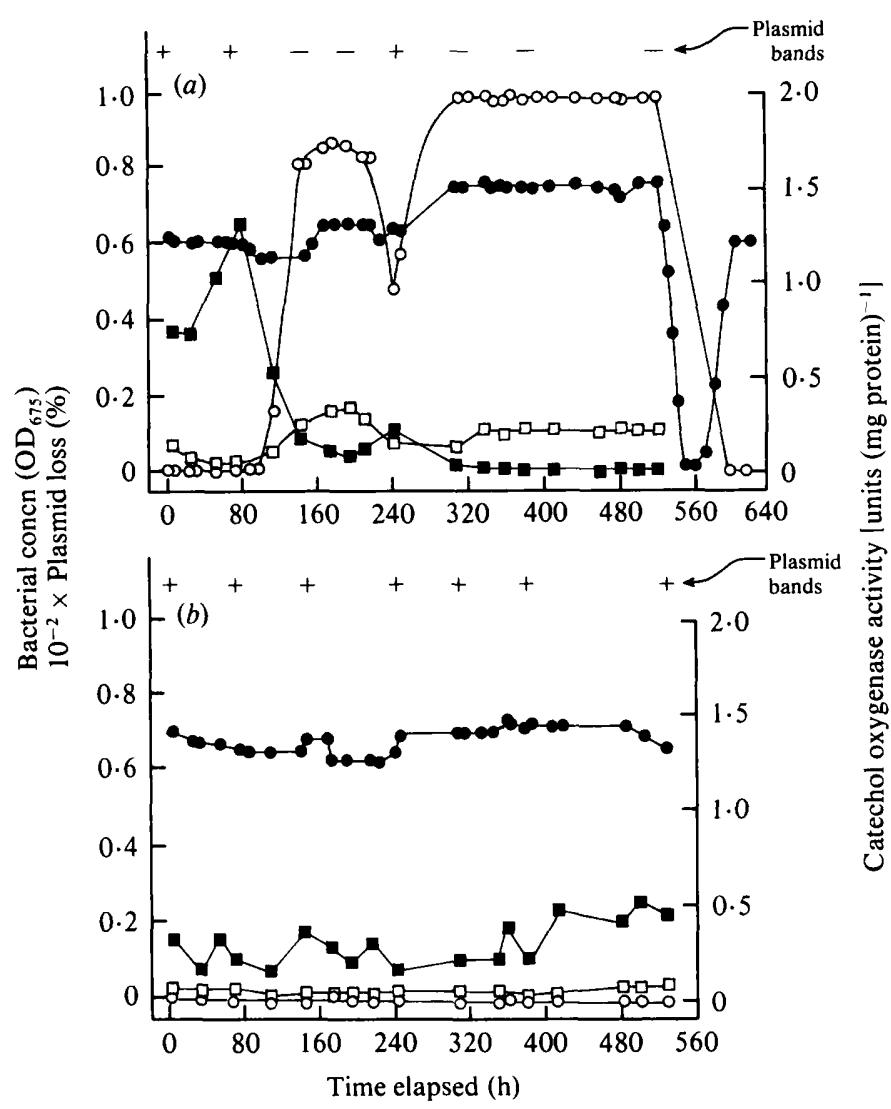

Fig. 4. Variations in plasmid stability of strain PPK6 in continuous culture with benzoate as the growth-limiting carbon source. Cultures were grown to steady state on $m$-toluate $(5 \mathrm{mM})$ and the incoming medium was switched to benzoate $(5.5 \mathrm{~mm})$. The elapsed time is shown for growth on benzoate (stage $\mathrm{C}$ ). $\bullet$, Bacterial concentration as $\mathrm{OD}_{675} ; \mathrm{O}$, percentage plasmid loss; $\square$, catechol 1,2oxygenase; $\mathbf{a}$, catechol 2,3-oxygenase. Both culture vessels $(a)$ and $(b)$ were inoculated with PPK6 isolated from stage $\mathrm{C}$ of growth on benzoate as shown in Fig. 3. Fig. 4(a) includes the transition from benzoate to $m$-toluate and the recovery of the $\mathrm{Tol}^{+}$phenotype. Samples were used for isolation of plasmid DNA; the times at which plasmid bands were detected are shown at the top of the figure (+, plasmid band on gel; -, no plasmid band).

loss reached $99 \%$ after about $150 \mathrm{~h}$ growth on benzoate there was a later recovery of $\mathrm{Tol}^{+}$ bacteria in the population. In another experiment with PPK $1^{*}$ as the inoculum (not shown) the oscillations were greater. The apparent plasmid loss was $44 \%$ after $142 \mathrm{~h}$ and then fluctuated between $40 \%$ and $14 \%$. During $240 \mathrm{~h}$ growth with benzoate-limitation there was no time at which the plasmid loss was greater than $44 \%$.

In an attempt to continue this selection for increased stability, $\mathrm{Tol}^{+}$bacteria were isolated from the PPK 1* experiment (Fig. 3) as PPK6. Two chemostats were inoculated with PPK6 and run in parallel under identical conditions (Fig. $4 a, b$ ). With one of these there were marked oscillations in apparent plasmid levels. Plasmid loss was detected after $115 \mathrm{~h}$ growth on benzoate and reached $87 \%$ after $180 \mathrm{~h}$. Thereafter there was a rapid recovery of $\mathrm{Tol}^{+}$bacteria followed by a dramatic decline to give $99 \%$ loss at $312 \mathrm{~h}$. The optical density of the culture and the enzyme activities also fluctuated and the typical changes of colour from pale to deep green and back were observed during the periods of oscillation of plasmid levels in the chemostat culture. Fig. 4(a) also shows the usual rapid plasmid recovery during stage D after the return to growth on $m$-toluate. On the other hand, in the parallel experiment (Fig. $4 b$ ) there was no plasmid loss during $500 \mathrm{~h}$ growth on benzoate. 
Stability of the PPKI TOL plasmid in continuous culture with succinate as carbon-limiting growth substrate

Succinate is a catabolite repressor for many induced enzymes of Pseudomonas species and in some cases its role as a preferred growth substrate in manifested in diauxic growth. Continuous culture experiments were set up as previously with cultures established in steady state growth on $m$-toluate before switching to growth on succinate. There were no significant fluctuations in optical density after the transition to succinate and the cultures remained in steady state growth on succinate for periods of $300-600 \mathrm{~h}$ with no detectable plasmid loss.

\section{$\mathrm{Tol}^{-}$isolates from chemostat culture}

The fluctuations in apparent plasmid levels could have been due to total loss of plasmid, to repression of plasmid genes or to inactivation by integration of the plasmid into the chromosome followed by intermittent release. If the latter had occurred it was possible that $\mathrm{Tol}^{-}$bacteria isolated from benzoate growth, stage $\mathrm{C}$, would be able to recover the $\mathrm{Tol}^{+}$character spontaneously. A chemostat was set up with benzoate as the carbon-limiting growth substrate and inoculated with strain PPK2, a Tol- isolate from the experiment shown in Fig. $1(b)$. The culture was maintained in steady state with benzoate for $47 \mathrm{~h}$ and then switched to $m$-toluate. The optical density dropped from 0.55 to 0.06 in $5 \mathrm{~h}$ and after $21 \mathrm{~h}$ was 0.01 . The medium feed was turned off and the culture left for a further $20 \mathrm{~h}$. There was no growth and no $\mathrm{Tol}^{+}$bacteria were detected. The curing appeared to be irreversible.

\section{Isolation of plasmid DNA from chemostat cultures}

A single plasmid band, running more slowly than pWW0 from strain PaW1 (used as control), was detected in samples from growth on $m$-toluate and during growth on benzoate before apparent plasmid loss. No plasmid DNA could be detected in the cured strain PPK 2 or in samples taken from chemostat runs during stage $\mathrm{C}$ at times at which it appeared that plasmid loss had reached about $98 \%$. Plasmid DNA was detected in all samples removed from the PPK6 experiment shown in Fig. 4(b). The times at which plasmid bands could be detected in samples from the PPK6 experiment shown in Fig. 4(a) corresponded to the times at which plasmid loss had been inferred from the observations made on growth phenotype and enzyme activities. In the sample taken at $244 \mathrm{~h}$ ( $55 \%$ loss), a plasmid band was seen but was fainter than in the samples taken during the earlier stages up to $100 \mathrm{~h}$. No differences in mobility were detected, so the plasmid did not appear to have lost or gained any significant amounts of DNA during the experimental period. Although small changes could not be ruled out it was concluded that the observations on growth phenotype and enzyme activities were related to retention or loss of the entire plasmid. The size was estimated from the mobilities of the plasmid bands and from restriction enzyme digests (not shown) to be approximately $150 \mathrm{~kb}$. The TOL plasmids isolated by Williams \& Worsey (1976) ranged in size from 70 to $200 \mathrm{~kb}$.

\section{Non-transmissibility of plasmid pTKO from $P$. putida PPKI}

No recombinants were obtained in plate matings with PPK1 as donor and PPK2 (cured strain) or PaW 17 as recipients but the pTK0 plasmid from strain PPK 1 could be mobilized by the IncP-1 plasmid pMO61. Although the plasmid pTK0 of strain PPK1 was not selftransmissible it was thought that some of the variants isolated from the chemostats might be altered in this respect. However, none gave transconjugants in plate matings with any of the potential recipients.

The further possibility remained that during the rapid recovery of the $\mathrm{Tol}^{+}$character after the chemostat culture had been returned from benzoate to $m$-toluate at stage $D$, the transfer functions were derepressed with consequent rapid spread of the plasmid through the population. Samples removed from the chemostat at this stage were tested for donor activity by patch plate mating and by membrane mating. No donor activity was detected and it was concluded that conjugal transfer of pTK0 played no part in the changes in the growth phenotype of the chemostat population at any growth stage. 


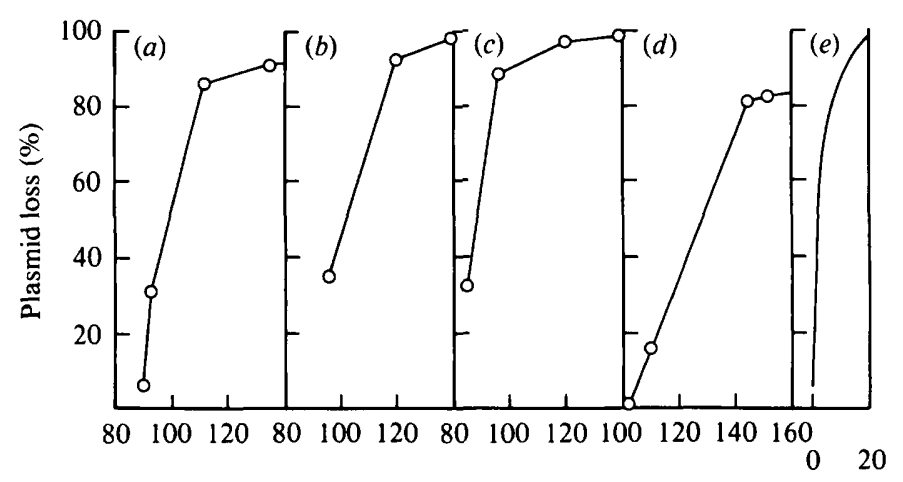

Time elapsed (h)

Fig. 5. Rates of loss of TOL plasmids from $P$. putida strains growing with benzoate as growth-limiting carbon source. The data are taken from the experiments shown in Figs 1, 3 and 4(a) and the curves are plotted for the period during which the numbers of plasmid-containing bacteria declined most rapidly. (a) PPK 1 from Fig. 1(a); (b) PPK1 from Fig. 1(b); (c) PPK1* from Fig. 3; (d) PPK6 from Fig. 4(a); (e) is the theoretical washout curve at the dilution rate of $0.2 \mathrm{~h}^{-1}$.

\section{Kinetics of plasmid loss in continuous culture}

$P$. putida strain PPK 1 retained its TOL plasmid for about $100 \mathrm{~h}$ when grown in continuous culture under benzoate-limitation and thereafter the numbers of plasmid-containing bacteria declined to about $1 \%$ of the total population. Strains PPK ${ }^{*}$ and PPK6, isolated from samples taken after prolonged growth on benzoate in continuous culture, retained their plasmids for longer periods. In one experiment with strain PPK6 as the inoculum there was no plasmid loss during $500 \mathrm{~h}$ continuous culture on benzoate (Fig. $4 b$ ).

In Fig. 5 we have plotted the rates of plasmid loss over the period of rapid decline in numbers for the experiments shown in Figs 1, 3 and 4(a). We have also included the theoretical curve for washout of the plasmid-containing bacteria from the chemostat population (Fig. $5 e$ ).

The classical explanation for the decline in numbers of plasmid-containing bacteria is that plasmid-free bacteria grow faster. This would give simple competition kinetics and the rate of replacement would depend on the growth advantage of the plasmid-free strain (Powell, 1958; Dykhuizen \& Hartl, 1983). Assuming a linear correlation of $\ln \left[X_{1}(t) / X_{2}(t)\right]$ with time, with $X_{1}(t)$ and $X_{2}(t)$ representing the relative proportions of the two competing strains at time $t$, it can be calculated from the data shown in Fig. $5(a-d)$ that it would be necessary to have a growth advantage of between 0.13 and $0.25 \mathrm{~h}^{-1}$ to account for the observed rates of decline in plasmidcontaining bacteria. From these values it would be predicted that there would be marked differences in the growth rates of the $\mathrm{Tol}^{+}$and $\mathrm{Tol}^{-}$bacteria, and the plasmid-containing strain would be expected to disappear completely with time, but this never occurred in any of our experiments. After an initial period of plasmid loss there was often a marked recovery; in one experiment the plasmid level did not drop below $44 \%$ and in another the plasmid was retained throughout the experimental period.

We need to account for the event leading to the initial loss of plasmid from one or more of the original population. Among other possibilities is that this event is due to a failure in partitioning (Nordstrom et al., 1980a,b). If we assume a negligible difference in the growth rates of the Tol ${ }^{+}$ and Tol- $^{-}$bacteria then, using the data shown in Fig. 5, the percentage loss of plasmid per generation varies from $20 \%$ to $40 \%$, which could mean that correct partitioning of plasmid copies into both daughter cells occurs in between $20 \%$ and $60 \%$ of the dividing cells. Assuming no further plasmid replication after the initial catastrophe, and initially one plasmid copy per cell, a change from $32 \%$ to $88 \%$ plasmid loss would take about $8.7 \mathrm{~h}$. In the experiment with PPK $1^{*}$ (Fig. $5 c$ ) this took place in $11 \mathrm{~h}$ so that the rate of plasmid loss is approaching that for washout (Fig. $5 e$ ). We have taken the extreme case but we know that limited plasmid replication and segregation does occur since some plasmid-containing bacteria remain in the population. 
DISCUSSION

The maintenance of plasmids in bacterial cells presents a paradox. Under certain growth conditions plasmid-containing strains are at an advantage compared with plasmid-free strains. On the other hand it may be disadvantageous for an organism to carry DNA that is not required for immediate needs. This argument holds less force now that it is known that plasmids are present in many organisms, that bacteria may carry genes for cryptic pathways and that genes for multiple catabolic pathways may exist in some organisms. The identification of several plasmids, some very large, in species of Rhizobium and Pseudomonas (Rosenberg et al., 1982) suggests that the maintenance of plasmids is a complex and well-regulated process. However, it is also a common observation that bacteria isolated for their interesting catabolic activities may be rather unstable in laboratory culture.

In our experiments the TOL plasmid of PPK1 was lost during benzoate-limited growth. Although each chemostat experiment is a unique exercise in the evolution of a bacterial population it has frequently been observed that periodic selection events are relatively reproducible (Dykhuizen \& Hartl, 1983). Starting with the wild-type strain PPK1 the time at which the plasmid-free strains appeared was around $100 \mathrm{~h}$. Even in experiments in which the frequency of the plasmid-free population remained constant at about $98 \%$ for long periods the plasmid-containing strain was never completely lost and could recover to become $100 \%$ of the population when the selection pressure was reimposed.

When PPK 1 was grown under succinate-limitation its TOL plasmid was stably maintained for up to $600 \mathrm{~h}$. Under these conditions the enzymes of the aromatic pathways are not induced and one possible interpretation is that the plasmid is more stable when the catabolic genes are not expressed. This implies that replication of the plasmid DNA is not a disadvantage to the host bacterium but that gene expression may be. Our experiments with the variant strains selected from continuous growth on benzoate indicate that some plasmids can be maintained for long periods even when there is good gene expression. In one experiment the plasmid of PPK6 was stably maintained in continuous culture with benzoate for over $500 \mathrm{~h}$. In this case the plasmid-coded catabolic genes were fully expressed. The increased stability in PPK6 could have been due to either plasmid or chromosomal factors but was not an irreversible change since in another experiment, set up at the same time and with the same inoculum, the plasmidcontaining bacteria eventually dropped to $1 \%$ of the population.

The possession of catabolic plasmids, or drug resistance plasmids, provides bacteria with genes that may be useful under particular growth conditions. The TOL plasmids have the unusual property of replacing a catabolic pathway coded by chromosomal genes by a pathway coded by plasmid genes. With the TOL plasmid present benzoate is degraded by the meta cleavage pathway and in its absence by the ortho cleavage pathway. It has been suggested that the TOL plasmid is lost in batch culture because the ortho cleavage pathway allows faster growth of $P$. putida (arvilla) mt-2 on benzoate (Williams \& Murray, 1974) and we had thought that we might observe this in continuous culture with strain PPK1. If the growth rate on benzoate via the ortho cleavage pathway were to be significantly higher than that via the meta cleavage pathway, that could account for the replacement of plasmid-containing strains by plasmid-free strains but not for plasmid recovery. However, the growth rates of strains PPK1 and PPK 2 in batch culture do not differ significantly and considerable growth rate differences would be required to account for the very rapid loss of plasmids observed in our continuous culture experiments.

Competition in chemostat culture could also be affected by differences between the activities of the chromosomal and plasmid benzoate oxidases, the 1,2- and 2,3-catechol oxygenases and other enzymes of the two pathways. Since the synthesis of the plasmid-coded enzymes is regulated by a different mechanism from that controlling the chromosally-coded enzymes, both the substrate affinities and the amounts of the enzymes synthesized could be important. Also, many aromatic substrates and their metabolic intermediates are toxic at relatively low concentrations. Benzoate was present in the incoming medium at a growth-limiting concentration $(5.5 \mathrm{mM})$ but there could have been transient accumulation of toxic intermediates 
of the meta pathway. This might give an advantage to the plasmid-free bacteria. We do not rule out the possibility that these factors may contribute to competition between the plasmid-free and plasmid-containing strains.

We observed oscillations in the frequencies of the plasmid-free and plasmid-containing bacteria which varied in extent in different experiments and were more marked with strains isolated after prolonged growth under benzoate-limitation. Helling et al. (1981) observed oscillations in chemostat culture of an Escherichia coli strain carrying a small non-conjugative plasmid and they suggested that the frequency of the plasmid-free population increased principally because the bacteria had a higher growth rate but also because of occasional defective segregation. The spontaneous mutations resulting in a faster growth rate were expected to occur more frequently among the plasmid-containing bacteria since these constituted the bulk of the population. However in our experiments the oscillations, and the increase in frequency of the plasmid-containing bacteria, appeared at times at which the plasmid-free population was dominant.

It has now become possible to relate some changes in plasmid properties to specific alterations in DNA structures. Genes carried on transposons may be exchanged between different replicons; genes may be inactivated by the insertion of IS sequences; single-site mutations or duplication of gene sequences may alter gene expression (see Bukhari et al., 1977). A duplicated sequence in the drug resistance plasmid R68.45 is thought to account for its acquisition of chromosome-mobilizing ability and further modifications confer the ability to generate Rprimes (Willetts et al., 1981; Morgan, 1982). The DNA of TOL plasmids has been shown to be capable of extensive rearrangement during selection for new activities (Jeenes et al., 1982; Kunz \& Chapman, 1981).

We suggest that it may be possible to relate our observations on the stability of the TOL plasmid of PPK 1 in continuous culture to factors affecting the control of plasmid replication and segregation. Nordstrom et al. $(1980 a, b)$, working with drug-resistance plasmids, concluded that plasmid partitioning is tightly controlled. They found that plasmid R1drd-19 was stably inherited while certain mini-plasmid derivatives with par deletions were less stable and they concluded that plasmid $\mathrm{R} 1 d r d-19$ carries a region controlling the plasmid segregation at cell division. Meacock \& Cohen (1980) identified a cis-acting locus, par, that accomplishes stable inheritance of $\mathrm{pSC101}$. Similar findings on the importance of par functions for accurate partitioning of plasmids allowing stable inheritance have been reported by other workers (Haakkart et al., 1982; Jones et al., 1980; Seelke et al., 1982). The mechanism of partitioning is not yet understood although the par region of pSC101 has now been sequenced (Meacock \& Cohen, 1980; Miller et al., 1983). Austin \& Wierzbicki (1984) identified two proteins encoded by the par sequence of mini-F plasmids that were essential for equipartition at cell division.

The regulation of partitioning is clearly important for plasmid maintenance in a population. It could also be an evolutionary advantage to have a means of slippage so that catabolic plasmids could be maintained in a small percentage of a natural population in the absence of any selection pressure.

We are grateful to Professor P. A. Williams for providing strain PaW17 and to Dr A. F. Morgan for providing plasmid pMO61 in strain PAO127.

\section{REFERENCES}

Austen, R. A. \& DunN, N. W. (1977). A comparative study of the NAH and TOL catabolic plasmids in Pseudomonas putida. Australian Journal of Biological Sciences 30, 357-366.

Austin, S. \& WIERzBICKI, A. (1984). Two mini-Fencoded proteins are essential for equipartition. Plasmid 10, 73-81.

Brammar, W. J. \& Clarke, P. H. (1964). Induction and repression of Pseudomonas aeruginosa amidase. Journal of General Microbiology 37, 307-319.
Bukhari, A. I., Shapiro, J. A.\& Adhya, S. L. (editors) (1977). DNA Insertion Elements, Plasmids and Episomes. New York: Cold Spring Harbor Laboratory.

Dykhuizen, D. E. \& Harti, D. L. (1983). Selection in chemostats. Microbiological Reviews 47, 150 168.

Godwin, D. \& Slater, J. H. (1979). The influence of the growth environment on the stability of a drug resistance plasmid in Escherichia coli K12. Journal of General Microbiology 111, 201-210. 
Hakkaart, M. J. J., Veltkamp, E. \& Nijkamp, H. J. J. (1982). Maintenance of the bacteriogenic plasmid CloDF13 in Escherichia coli cells. II. Specific recombination functions involved in plasmid maintenance. Molecular and General Genetics 188, 338344.

Hegeman, G. D. (1966). Synthesis of the enzymes of the mandelate pathway by Pseudomonas putida. 1 . Synthesis of enzymes by the wild type. Journal of Bacteriology 91, 1140-1154.

Helling, R. B., Kinney, T. \& Adams, J. (1981). The maintenance of plasmid-containing organisms in populations of Escherichia coli. Journal of General Microbiology 123, 129-141.

INDERLIED, C. B. \& MORTLOCK, R. P. (1977). Growth of Klebsiella aerogenes on xylitol: implications for bacterial evolution. Journal of Molecular Evolution 9 , 181-190.

JACOBY, G. A. (1974). Properties of R plasmids in Pseudomonas aeruginosa. In Microbiology - 1974, pp. 36-42. Edited by D. Schlessinger. Washington, DC: American Society for Microbiology.

JeEnes, D. J., ReINECKe, W., KNACKMuss, H.-J. \& WILliams, P. A. (1982). The TOL plasmid pWW0 in constructed halobenzoate degrading Pseudomonas strains: enzyme regulation and DNA structure. Journal of Bacteriology 150, 180-187.

Jones, I. M., Primrose, S. B., Robinson, A. \& Ellwood, D. C. (1980). Maintenance of some ColEl-type plasmids in continuous culture. Molecular and General Genetics 180, 579-584.

Kanemitsu, H., Fukuda, M. \& Yano, K. (1980). Plasmid-borne biodegradation of toluene and ethylbenzene in a pseudomonad. Journal of Fermentation Technology 58, 175-181.

KunZ, D. A. \& Chapman, P. J. (1981). Isolation and characterization of spontaneously occurring TOL plasmid mutants of Pseudomonas putida HS1. Journal of Bacteriology 46, 952-964.

MeACOCK, P. A. \& CoHen, S. N. (1980). Partitioning of bacterial plasmids during cell division: a cis-acting locus that accomplishes stable plasmid inheritance. Cell 20, 529-542.

Melling, J., Ellwood, D. C. \& Robinson, A. (1977). Survival of R-factor carrying Escherichia coli in mixed cultures in the chemostat. FEMS Microbiology Letters 2, 87-89.

Miller, C. A., Tucker, W. T., Meacock, P. A., Gustafsson, P. \& Cohen, S. N. (1983). Nucleotide sequence of the partition locus of Escherichia coli plasmid pSC101. Gene 24, 309-315.

MORGAN, A. F. (1982). Isolation and characterization of Pseudomonas aeruginosa $\mathrm{R}$ plasmids constructed by interspecific mating. Journal of Bacteriology 149 , 654-661.
NordSTROM, K. (1983). Control of plasmid replication. Plasmid 9, 1-7.

Nordstrom, K., Molin, A. \& AagaARd-Hansen, H. $(1980 a)$. Partitioning of plasmid R1 in Escherichia coli. I. Kinetics of loss of plasmid derivatives deleted of the par region. Plasmid 4, 215-227.

Nordstrom, K., Molin, S. \& AagaARd-Hansen, H. $(1980 \mathrm{~b})$. Partitioning of plasmid R1 in Escherichia coli. II. Incompatibility properties of the partitioning system. Plasmid 4, 332-349.

Powell, E. O. (1958). Criteria for the growth contaminants and mutants in continuous culture. Journal of General Microbiology 18, 259-268.

Rigby, P. W. J., Burleigh, B. D. \& Hartley, B. S. (1974). Gene duplication in experimental enzyme evolution. Nature, London 251, 200-204.

Rosenberg, C., Casse-Delbart, F., Dusha, I., David, M. \& Boucher, C. (1982). Megaplasmids in the plant-associated bacteria Rhizobium meliloti and Pseudomonas solanacearum. Journal of Bacteriology 150, 402-406.

Sala-Trepat, J. M. \& Evans, W. C. (1971). The meta cleavage of catechol by Azotobacter species 4oxalocrotonate pathway. European Journal of Biochemistry 20, 400-413.

Seelke, R. W., Kline, B. C., Trawick, J. D. \& Ritts, G. D. (1982). Genetic studies of F plasmid maintenance genes involved in copy number control, incompatibility, and partitioning. Plasmid 7, 163179.

Stanier, R. Y., Palleroni, N. J. \& DoudorofF, M. (1966). The aerobic pseudomonads: a taxonomic study. Journal of General Microbiology 43, 159-271.

Wheatcroft, R. G. \& Williams, P. A. (1981). Rapid methods for the study of both stable and unstable plasmids in Pseudomonas. Journal of General Microbiology 124, 433-437.

Willetts, P. A., Crowther, C. \& Holloway, B. W. (1981). The insertion sequence IS21 of R68.45 and the molecular basis for mobilization of the bacterial chromosome. Plasmid 6, 30-52.

Williams, P. A. \& MurRay, K. (1974). Metabolism of benzoate and the methylbenzoates by Pseudomonas putida (aritlla) mt-2: evidence for the existence of a TOL plasmid. Journal of Bacteriology 120, 416-423.

Williams, P. A. \& WoRsey, M. J. (1976). Ubiquity of plasmids in coding for toluene and xylene metabolism in soil bacteria: evidence for the existence of new TOL plasmids. Journal of Bacteriology 125, 818828.

ZUND, P. \& LEBEK, G. (1980). Generation timeprolonging $\mathrm{R}$ plasmids: correlation between increases in the generation time of Escherichia coli caused by $\mathrm{R}$ plasmids and their molecular size. Plasmid 3, 65-69. 